\title{
Water Filterable and Particulate Metals and Their Bioaccumulation in Prawns along Veifa Village, Central Province, Papua New Guinea
}

\author{
John Kia Nema ${ }^{1}$, Stewart Wabo Wossa ${ }^{1}$, Basil Marasinghe ${ }^{1}$ and Kulange John Banda ${ }^{2}$ \\ 1. Department of Chemistry, University of Goroka, Goroka 441, Papua New Guinea \\ 2. Department of Geology, University of Papua New Guinea, Port Moresby 121, Papua New Guinea
}

\begin{abstract}
Toxic metals are released into the river systems from both anthropogenic activities and natural sources. These metals are present in water as filterable and particulate metals. These metals were found to bioaccumulate in prawn samples along Veifa stretch of the Angabanga River. The analytical results showed that As as particulate metal was high in concentration at $86 \mu \mathrm{g} \cdot \mathrm{g}^{-1}$ and $\mathrm{Pb}$ as filterable metal was high in concentration at $12 \mu \mathrm{g} \cdot \mathrm{g}^{-1}$. The metals $\mathrm{Pb}$ and As also accumulated in prawns along the Veifa stretch but were within recommended toxic metal standards.
\end{abstract}

Key words: Bioaccumulation, metal concentration, Veifa stretch, prawns.

\section{Introduction}

The fate of toxic metals in the environment must be established as these metals are known cumulative toxins. These metals are found to be carcinogenic and cause cancer when exposed in large amounts [1-3]. A study by Jarup [3] showed that $\mathrm{As}, \mathrm{Pb}$ and $\mathrm{Hg}$ are highly toxic and have severe health implications when they bioaccumulate in water and aquatic organisms. The increased level of metals causes negative impacts on prawns and other food resources [4].

Therefore, the primary aim of this study is to investigate concentration of filterable metals and particulate metals. Thus, establish their concentrations and compare recommended environmental standards with the intention to reduce metals pollution in the river systems.

\section{Materials and Methods}

\subsection{Sampling}

\subsubsection{Water Samples}

Water samples were collected at two locations

Corresponding author: John Kia Nema, B.Sc., research field: environment chemistry. E-mail: nemajohn9@gmail.com. along the Veifa stretch of the Angabanga River. Water samples were collected at a depth of about $0.5 \mathrm{~m}$. The polyethylene sample bottle was immersed $20 \mathrm{~cm}$ below the surface before turning it towards the stream flow and treated with $10 \% \mathrm{HNO}_{3}$ for those samples to be analysed for metals. This treatment prevents adsorption of dissolved metals, colligation and possible complexing of metals. The samples were sealed, labelled and stored in an esky and transported to University of Goroka research laboratory.

\subsubsection{Prawns Samples}

Three fresh water prawns samples of the thumbnail species of the crustaceae sub-phylum were also collected from the same locations where water samples were collected. The samples were stored in plastic bag on ice, sealed and transported back to University of Goroka research laboratory in an esky.

\subsection{Sample Preparation and Digestion}

\subsubsection{Water Samples}

Raw water samples were filtered to remove undissolved solid particles before digestion.

Fifty milliliter of the filtered water sample was 
digested with $30 \mathrm{~mL}$ aqua regia on a hot plate. A clear solution was noticed with no fumes for the completion of digestion process. Twenty five milliliter of the digested sample was topped up in a $100 \mathrm{~mL}$ volumetric flask with 15\% HCL to keep the target analytes in solution before instrumental analysis. The digested samples were tightly sealed and labelled.

\subsubsection{Prawns Sample}

About $3 \mathrm{~g}$ dried fresh water prawns sample from each site was digested using $25 \mathrm{~mL}$ nitric/perchloric acid. After the completion of the digestion process, 5 $\mathrm{mL}$ of the digested sample was topped up in a $25 \mathrm{~mL}$ volumetric flask with 15\% HCL. The digested samples were tightly sealed and labelled for instrumental analysis.

\subsection{Analytical Methods}

The prepared samples were analysed for the targeted analytes $(\mathrm{Hg}, \mathrm{As}$ and $\mathrm{Pb})$ at the NAL (National Analysis Laboratory). The metals were analysed using AAS (atomic absorption spectrophotometer) while $\mathrm{Hg}$ was analysed using mercury analyzer.

\section{Results and Discussion}

\subsection{Potential Metal Sources}

The Veifa stretch is located approximately $50 \mathrm{~km}$ downstream of Tolukuma Gold Mine. The metals (As, $\mathrm{Pb}$ and $\mathrm{Hg}$ ) may be introduced into the environment from their primary ores (arsenopyrite, galena or

Table 1 Filterable metals $\left(\mathrm{mg} \cdot \mathrm{L}^{-1}\right)$ and particulate metals $\left(\mu \mathrm{g} \cdot \mathrm{g}^{-1}\right)$ in water.

\begin{tabular}{lll}
\hline Water samples & Target metals & \\
\hline & $\mathrm{Pb}$ & 12 \\
W001 (filterable metals) & $\mathrm{As}$ & $<0.0002$ \\
& $\mathrm{Hg}$ & $<0.0002$ \\
\hline & $\mathrm{Pb}$ & 14 \\
W002 (particulate metals) & $\mathrm{As}$ & 86 \\
& $\mathrm{Hg}$ & $<0.2$ \\
\hline
\end{tabular}

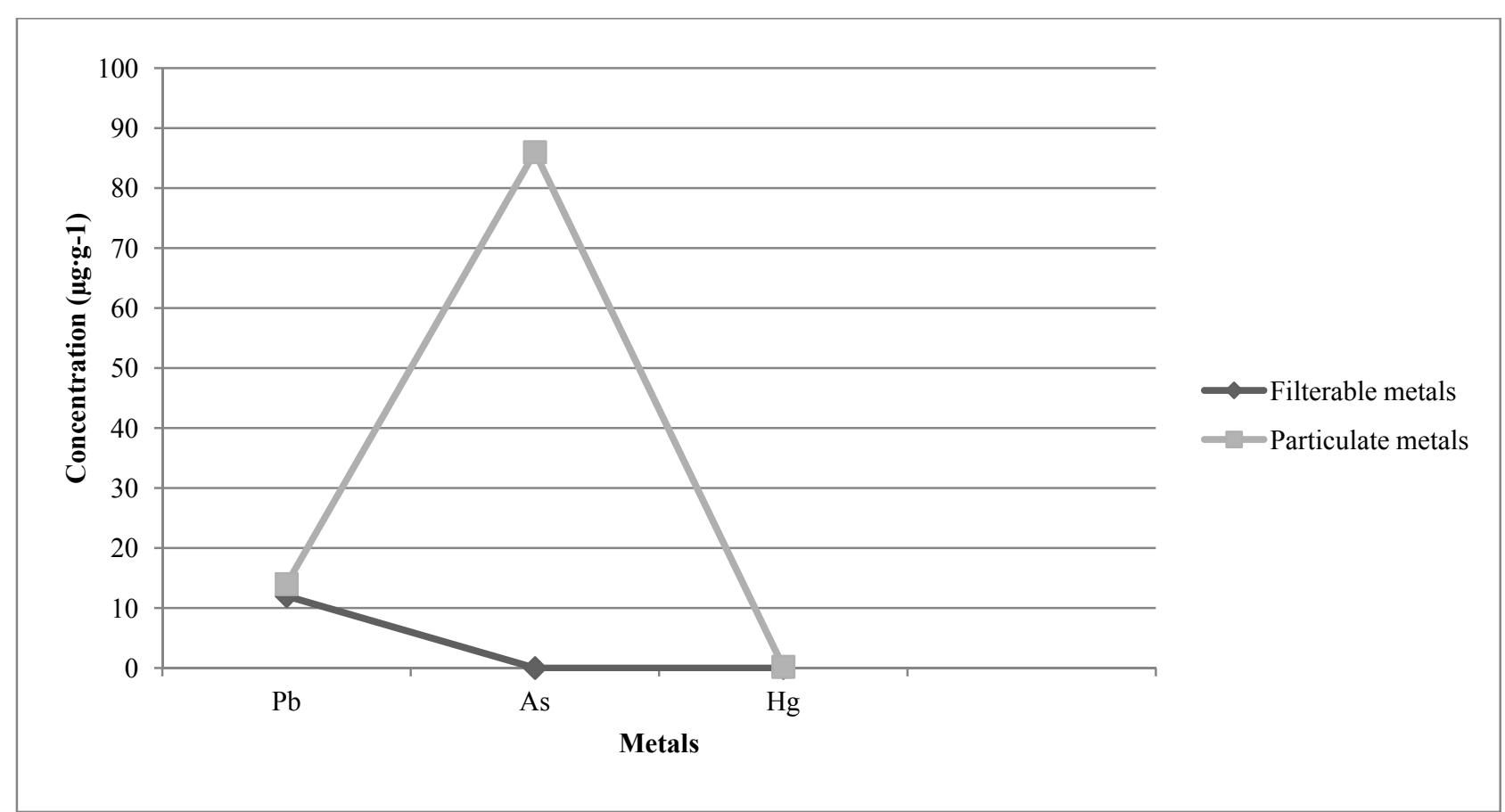

Fig. 1 Plot of metal concentration in water: filterable $\left(\mathrm{mg} \cdot \mathrm{L}^{-1}\right)$ and particulate $\left(\mu \mathrm{g} \cdot \mathrm{g}^{-1}\right)$. 
Table 2 Metal concentration in prawn samples $\left(\mu \mathrm{g} \cdot \mathrm{g}^{-1}\right)$.

\begin{tabular}{llll}
\hline \multirow{2}{*}{ Prawn samples } & \multicolumn{3}{c}{ Target metals in prawns } \\
\cline { 2 - 4 } & As & $\mathrm{Pb}$ & $\mathrm{Hg}$ \\
\hline $1 \mathrm{a}$ & 0.1 & 0.42 & $<0.1$ \\
$\mathrm{2b}$ & 0.254 & 0.27 & $<0.1$ \\
$3 \mathrm{c}$ & 0.156 & 0.22 & $<0.1$ \\
\hline
\end{tabular}

*1a, $2 \mathrm{~b}$ and $3 \mathrm{c}$ are three different sites from which prawn samples are collected.

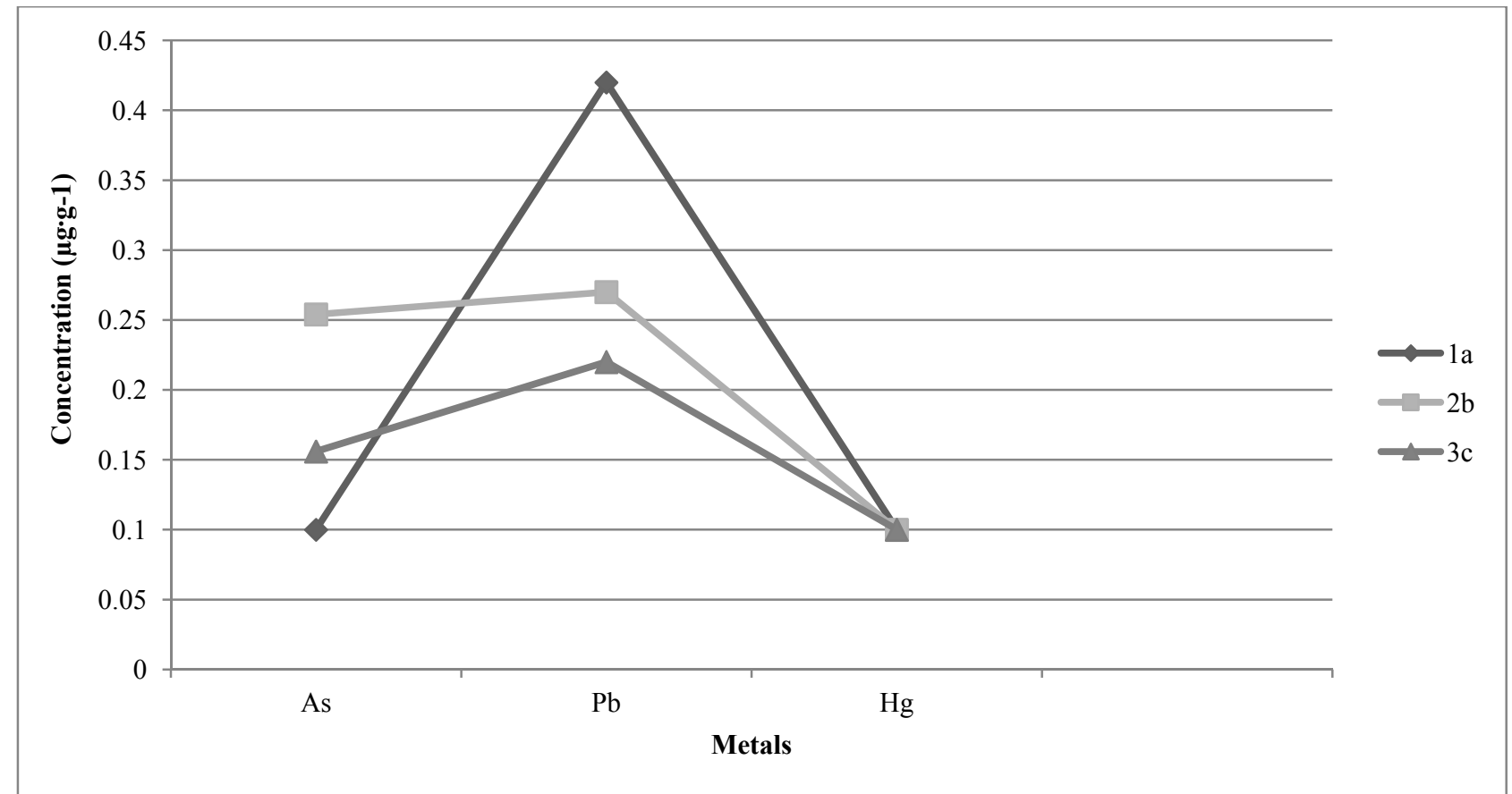

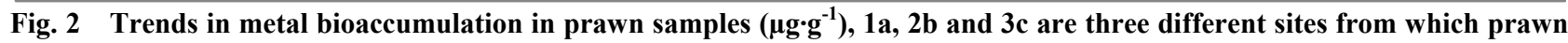
samples are collected.

cinnabar) if those ores occur upstream. These metals can equally be introduced into the environment after sulphide containing ores undergo acid rock drainage $[5,6]$.

Increased levels of heavy metals ( $\mathrm{Pb}, \mathrm{As}$ and $\mathrm{Hg}$ ) were found in water samples analysed for Auga-Angabanga River [7]. The most important sources for metals in the environment are mine tailings [8].

\subsection{Filterable and Particulate Metal Concentrations in Water}

The analytical results in Table 1 and Fig. 1 show that filterable $\mathrm{Pb}$ was high in concentration at 12 $\mu \mathrm{g} \cdot \mathrm{g}^{-1}$ and particulate As was high at $86 \mu \mathrm{g} \cdot \mathrm{g}^{-1}$. The reason for high particulate As the sample was taken from the water body that closer to a sedimentation area which acts as a reservoir of As. The concentration exceeded Papua New Guinea (PNG) drinking water standard of $50 \mathrm{mg} \cdot \mathrm{L}^{-1}$ and Australian Drinking Water Guideline (ADWG) standard of $7 \mathrm{mg} \cdot \mathrm{L}^{-1}$ and United States Environmental Protection Authority (USEPA) standard of $0.05 \mathrm{mg} \cdot \mathrm{L}^{-1}[9,10]$. As is a health hazard in the study locality and is also the reason for the accumulation in prawns samples.

\subsection{Bioaccumulation in Prawns}

The metals ( $\mathrm{Pb}$ and $\mathrm{As})$ significantly bioaccumulate in prawns samples given in Table 2 and Fig. 2, but within recommended standards for heavy metal content in food and crustaceae [11]. These metals will bioaccumulate and reach toxic levels with time. The 
variations in metal concentrations observed may be due to the different sizes of prawns sampled and the metals are not able to penetrate the exoskeleton as it is hard.

\section{Conclusion}

The metals in the environment come from their sources. Further study is required to critically comment on the natural sources of the metals in the water. Particulate As is high in concentration in water and is a health concern along Veifa stretch for the villagers.

\section{Acknowledgment}

The author acknowledges URPC (University of Goroka-PNG) for research grants for this study.

\section{References}

[1] Soghoian, S. 2006. "Toxicity, Heavy Metals." Accessed May 10 , 2007. http://www.emedicine.com/EMERG/topic237.htm.

[2] Banda, K. J., Jeyarathan, P., Treu, R., and Barish, A. 2005. "Medical Implications of Quantitative Analysis of Drinking Water in Goroka, EHP, Papua New Guinea." Presented at the National Medical Symposium, Goroka,
Eastern Highlands Province.

[3] Jarup, L. 2003. "Hazards of Heavy Metal Contamination." British Medical Bulletin 68 (1): 167-82.

[4] Macdonald, I. 2004. The Rights Based Approach to Mining Advocacy. Mining Ombudsman Annual report.

[5] Mills, C. 1995. Introduction to Acid Rock Drainage. Vancouver: Canadian Science Publishing.

[6] Skousen, J., Hilton, T., and Faulkner, B. 1997. Overview of Acid Mine Drainage Treatment with Chemicals. Pittsburgh, USA: American Society of Mining and Reclamation Publication.

[7] Tingay, A., and Tingay, S. R. 2004. Pollution from the Tolukuma Gold Mine in the Auga-Angabanga River System. Papua New Guinea: Oxfam Publishing.

[8] Florea, R. M., Stoica, A. I., Baiulescu, G. E., and Capota, P. 2005. "Water Pollution in Gold Mining Industry: A Case Study in Rosia Montana District, Romania." Journal of Environmental Geology 48 (8): 1132-6.

[9] Independent State of Papua New Guinea. 1984. Public Health (Drinking Water). Papua New Guinea: Government Publishing.

[10] Australia and New Zealand Environment and Conservation Council (ANZECC). 2000. Australia and New Zealand Guidelines for Fresh and Marine Water Quality. Canberra, Australia: Agriculture and Resource Management Council.

[11] Australia New Zealand Food Standard Code. 2001. Generally Expected Level (GEL). Australia: Canberra Publishing. 